\title{
Guillain-Barré Syndrome Associated With COVID-19
}

Seyed Amir Ebrahimzadeh, MD, MPH, Abdoreza Ghoreishi, MD, and Nasrin Rahimian, MD, MPH

Neurology: Clinical Practice April 2021 vol. 11 no. 2 e196-e198 doi:10.1212/CPJ.0000000000000879

\section{Correspondence}

Dr. Rahimian

dr.nasrin.rahimian@

gmail.com

In December 2019, the first case of pneumonia with unknown etiology was reported in Wuhan city, China. The identified pathogen was a novel coronavirus, severe acute respiratory syndrome coronavirus 2 (SARS-CoV-2). ${ }^{1}$ Since then, the virus has spread rapidly worldwide. Although coronavirus disease 2019 (COVID-19) typically presents with upper or lower respiratory symptoms, there have been rare reports of significant neurologic complications. ${ }^{2,3}$ Recently, a few reports presented cases of Guillain-Barré syndrome (GBS) after COVID-19. ${ }^{4,5}$ In this report, we describe 2 cases of GBS that occurred after COVID-19.

\section{Case 1}

In March 2020, a 46-year-old man came to the neurology clinic because of complaints of pain and numbness in distal lower and upper extremities for a week. In addition, progressive ascending weakness in legs had started 2 days back. The medical history revealed a history of low-grade fever, sore throat, dry cough, and mild dyspnea started 18 days before the first neurologic symptom onset. High-resolution chest CT scan (HRCT) at that time revealed multiple ground-glass opacities in peripheries of both lungs, typical for COVID-19, and the nasopharyngeal sample PCR confirmed the diagnosis. $\mathrm{He}$ had received hydroxychloroquine for 5 days. His respiratory symptoms improved after 10 days.

At the recent presentation, general physical examinations, including vital signs, were unremarkable. Neurologic examination revealed a mild peripheral facial nerve palsy on the right side. Muscles' forces were 4/5 in distal and proximal lower extremities according to the Medical Research Council (MRC) grading. The upper extremities showed no weakness. Deep tendon reflexes were absent in all 4 limbs. The electrodiagnostic study showed increased distal latencies in all 4 extremities. There was also symmetric nerve conduction slowing, suggestive of demyelinating polyneuropathy (table 1). An analysis of CSF revealed increased protein level $(78 \mathrm{mg} / \mathrm{dL}$, normal: $20-40 \mathrm{mg} / \mathrm{dL})$, and normal cell counts (erythrocyte $=0 / \mathrm{mm}^{3}$, normal: $0-10 / \mathrm{mm}^{3}$; leukocyte $=4 / \mathrm{mm}^{3}$, normal: $\left.0-5 / \mathrm{mm}^{3}\right)$ and glucose level $(70 \mathrm{mg} / \mathrm{dL}$, normal: $45-80 \mathrm{mg} / \mathrm{dL})$. Based on the clinical presentations and paraclinical findings, the diagnosis of GBS was established (table 2).

During admission, upper limb forces decreased to the MRC grade of $4 / 5$, and lower extremities' strength reduced to $3 / 5$ in distal and $4 / 5$ in proximal. The patient remained

\section{MORE ONLINE}

COVID-19 Resources

For the latest articles, invited commentaries, and blogs from physicians around the world NPub.org/COVID19

Department of Radiology (SAE), Yasrebi Hospital, Kashan, Esfahan; Department of Neurology (AG), School of Medicine, Zanjan University of Medical Sciences, Zanjan; and Department of Neurology (NR), Yasrebi Hospital, Kashan, Esfahan, Iran.

Funding information and disclosures are provided at the end of the article. Full disclosure form information provided by the authors is available with the full text of this article at Neurology.org/cp. 
Table 1 Electrodiagnostic Study Findings in Case 1 and Case 2

\begin{tabular}{|c|c|c|c|c|c|c|c|c|c|c|c|c|}
\hline & \multirow[b]{3}{*}{ Studied Nerve } & \multirow{2}{*}{\multicolumn{3}{|c|}{$\begin{array}{l}\text { Motor study } \\
\text { Distal latency }(\mathrm{ms}) \\
\text { Amplitude (distal/ } \\
\text { proximal) }(\mathrm{mV}) \\
\text { Conduction velocity }(\mathrm{m} / \mathrm{s})\end{array}$}} & \multirow{2}{*}{\multicolumn{3}{|c|}{$\begin{array}{l}\text { Sensory study } \\
\text { Peak latency }(\mathrm{ms}) \\
\text { Amplitude }(\mu \mathrm{V}) \\
\text { Conduction velocity } \\
(\mathrm{m} / \mathrm{s})\end{array}$}} & \multirow{2}{*}{\multicolumn{3}{|c|}{$\begin{array}{l}\text { F wave } \\
\text { Latency (ms) }\end{array}$}} & \multicolumn{2}{|l|}{ EMG } \\
\hline & & & & & & & & & & & \multirow[b]{2}{*}{ Fibrillation } & \multirow[b]{2}{*}{ Recruitment } \\
\hline & & Right & Left & Normal & Right & Left & Normal & Right & Left & Normal & & \\
\hline \multirow{9}{*}{$\begin{array}{l}\text { Case } \\
1^{a}\end{array}$} & Median & 4.7 & 4.4 & $\leq 4.4$ & 4.2 & 3.9 & $\leq 3.5$ & Absent & Absent & $\leq 32$ & 0 & $\downarrow \downarrow$ \\
\hline & & $5.4 / 5$ & $6 / 6$ & $\geq 4$ & 17.1 & 18.1 & $\geq 20$ & & & & & \\
\hline & & 55 & 56 & $\geq 50$ & 48 & 50 & $\geq 50$ & & & & & \\
\hline & Ulnar & 3.5 & 3.8 & $\leq 3.3$ & 3.3 & 3 & $\leq 3.1$ & Absent & Absent & $\leq 32$ & +1 & $\downarrow \downarrow$ \\
\hline & & $\begin{array}{l}10.3 / \\
10.2 / \\
10\end{array}$ & $\begin{array}{l}12 / \\
11.1 / \\
12\end{array}$ & $\geq 6$ & 16 & 17 & $\geq 17$ & & & & & \\
\hline & & 45 & 49 & $\geq 50$ & 45 & 49 & $\geq 50$ & & & & & \\
\hline & $\begin{array}{l}\text { Tibial (motor and } \\
\text { F) and Sural } \\
\text { (sensory) }\end{array}$ & 5.9 & 5.6 & $\leq 5.8$ & 4.2 & 4.1 & $\leq 4.4$ & Absent & Absent & $\leq 56$ & +2 & $\downarrow \downarrow$ \\
\hline & & $8 / 7.6$ & $8.2 / 8$ & $\geq 4$ & 23 & 18 & $\geq 6$ & & & & & \\
\hline & & 39 & 40 & $\geq 40$ & 45.2 & 46.3 & $\geq 40$ & & & & & \\
\hline \multirow{9}{*}{$\begin{array}{l}\text { Case } \\
2^{\mathrm{a}}\end{array}$} & Median & 3.5 & 4.3 & $\leq 4.4$ & 3.4 & 3.5 & $\leq 3.5$ & Absent & Absent & $\leq 32$ & 0 & $\downarrow \downarrow$ \\
\hline & & $6 / 5.4$ & $\begin{array}{l}6.6 / \\
6.3\end{array}$ & $\geq 4$ & 21 & 26 & $\geq 20$ & & & & & \\
\hline & & 55 & 49 & $\geq 50$ & 54 & 53 & $\geq 50$ & & & & & \\
\hline & Ulnar & 2.9 & 3 & $\leq 3.3$ & 2.9 & 3.1 & $\leq 3.1$ & Absent & Absent & $\leq 32$ & 0 & $\downarrow \downarrow$ \\
\hline & & $\begin{array}{l}11.2 / \\
11 / \\
11\end{array}$ & $\begin{array}{l}11.5 / \\
11.6 / \\
11.4\end{array}$ & $\geq 6$ & 18 & 18.9 & $\geq 17$ & & & & & \\
\hline & & 58 & 55 & $\geq 50$ & 55 & 52 & $\geq 50$ & & & & & \\
\hline & $\begin{array}{l}\text { Tibial (motor } \\
\text { and F) and Sural } \\
\text { (sensory) }\end{array}$ & 5.1 & 6.4 & $\leq 5.8$ & 2.3 & 1.8 & $\leq 4.4$ & Absent & Absent & $\leq 56$ & 0 & $\downarrow \downarrow$ \\
\hline & & $\begin{array}{l}2.21 \\
0.97\end{array}$ & $\begin{array}{l}1.4 / \\
1.3\end{array}$ & $\geq 4$ & 11.9 & 14.4 & $\geq 6$ & & & & & \\
\hline & & 32.1 & 37.7 & $\geq 40$ & 48 & 52 & $\geq 40$ & & & & & \\
\hline
\end{tabular}

a The intervals between the first neurologic symptom and electrodiagnostic study were 10 days and 6 days for case 1 and case 2, respectively.

ambulatory and did not deteriorate more, so he received neither plasmapheresis nor intravenous immunoglobulin (IVIG). After 16 days of close monitoring, his muscle forces improved to near normal.

\section{Case 2}

In March 2020, a 65-year-old man presented with a progressive ascending lower and upper extremities weakness and paresthesia. His symptoms had started 4 days before the first visit. He also had a history of COVID-19 (confirmed by HRCT and nasopharyngeal sample PCR), which had started
10 days before his neurologic symptoms' onset. General physical examinations, including vital signs, were unremarkable except for fine crackles in both lungs. His neurologic examination showed decreased forces, MRC grade of $2 / 5$ at proximal and $3 / 5$ at distal lower limbs, and $4 / 5$ in both arms. His deep tendon reflexes were absent in both legs and decreased to $1+$ in the upper extremities.

His electrodiagnostic study revealed generalized increased distal latencies and absent $\mathrm{F}$ waves (table 1). As the findings were indicative of GBS (table 2), he received a course of IVIG. On the discharge day $($ day +14$)$, his muscle forces were MRC grade $4 / 5$ in all extremities. 
Table 2 Laboratory and Examination Findings

\begin{tabular}{llc}
\hline CRP $(\mathrm{mg} / \mathrm{L})$ (normal: 0-10) & Case 1 & \multicolumn{1}{c}{ Case $\mathbf{2}$} \\
\hline Screening for Campylobacter jejuni, HIV, EBV, CMV, influenza virus (type A and B), and HCV & Negative & Negative \\
\hline VDRL & Non-reactive & Negative \\
\hline Gq1b antibody & Normal & Negative \\
\hline Brain and spinal MRI & Normal \\
\hline Serum protein immunoelectrophoresis & Negative \\
\hline PMH for chronic diseases & None \\
\hline Upper motor neuron signs & Negative & Normal \\
\hline Urinary or fecal incontinency & Hypertension \\
\hline History of diarrhea & Negative \\
\hline
\end{tabular}

Abbreviations: $\mathrm{CMV}=$ cytomegalovirus; $\mathrm{CRP}=\mathrm{C}$-reactive protein; $\mathrm{EBV}=$ Epstein-Barr virus; $\mathrm{HCV}=$ hepatitis $\mathrm{C}$ virus; $\mathrm{HSV}=$ herpes simplex virus; $\mathrm{PMH}=$ past medical history; $\mathrm{VDRL}=$ venereal disease research laboratory test.

\section{Discussion}

We described 2 cases of GBS occurring several days after COVID-19. There are rare reported cases of GBS in association with coronaviruses other than COVID-19. In 2017, a case series presented 4 patients infected with the Middle East Respiratory syndrome Coronavirus who presented with symptoms suggestive of GBS. ${ }^{6}$ However, they did not report nerve conduction data and assumed intensive-care-unit neuropathy as a differential diagnosis.

One of the suggested mechanisms for the development of GBS is the molecular resemblance. An immune response triggered by previous infection cross-reacts with the peripheral nerve myelin sheath and causes its damage. Some viruses are known to be associated with GBS. These include the human influenza virus, cytomegalovirus, HIV, and Epstein-Barr virus. ${ }^{7}$

Our presented cases and also other recently published reports $^{4,5}$ suggest that the SARS-CoV-2 might trigger GBS.

In a pandemic situation, physicians should be aware of the risk of acute demyelinating polyneuropathy after COVID-19. Because the COVID-19 is extremely contagious, we suggest that the physicians evaluate newly diagnosed patients with GBS for this infection as a potential trigger.

\section{Study Funding}

No targeted funding reported.

\section{Disclosure}

The authors report no disclosures relevant to the manuscript. Full disclosure form information provided by the authors is available with the full text of this article at Neurology.org/cp.

\section{Publication History}

Received by Neurology: Clinical Practice April 27, 2020. Accepted in final form May 15, 2020.

Appendix Authors

\begin{tabular}{lll}
\hline Name & Location & Contribution \\
\hline $\begin{array}{l}\text { Seyed Amir } \\
\text { Ebrahimzadeh }\end{array}$ & $\begin{array}{l}\text { Department of Radiology, } \\
\text { Yasrebi Hospital, Kashan, } \\
\text { Iran }\end{array}$ & $\begin{array}{l}\text { Proposed the idea of } \\
\text { reporting the cases, } \\
\text { Interpretation of patients' } \\
\text { chest HRCTs, contributed } \\
\text { to writing the manuscript }\end{array}$ \\
\hline $\begin{array}{l}\text { Abdoreza } \\
\text { Ghoreishi }\end{array}$ & $\begin{array}{l}\text { Department of } \\
\text { Neurology, School of } \\
\text { Medicine, Zanjan }\end{array}$ & $\begin{array}{l}\text { Diagnosing and } \\
\text { treatment of case 2, } \\
\text { contributed to writing the } \\
\text { manuscript }\end{array}$ \\
\hline $\begin{array}{l}\text { Sciences, Zanjan, Iran } \\
\text { Rasrin }\end{array}$ & $\begin{array}{l}\text { Department of } \\
\text { Neurology, Yasrebi } \\
\text { Hospital, Kashan, Iran }\end{array}$ & $\begin{array}{l}\text { Diagnosing and } \\
\text { treatment of case 1, } \\
\text { contributed to writing the } \\
\text { manuscript }\end{array}$ \\
\hline
\end{tabular}

\section{References}

1. Li JY, You Z, Wang Q, et al. The epidemic of 2019-novel-coronavirus (2019-nCoV) pneumonia and insights for emerging infectious diseases in the future. Microbes Infect 2020;22:80-85

2. Wu Y, Xu X, Chen Z, et al. Nervous system involvement after infection with COVID19 and other coronaviruses. Brain Behav Immun 2020;S0889-1591(20)30357-3. doi 10.1016/j.bbi.2020.03.031.

3. Poyiadji N, Shahin G, Noujaim D, Stone M, Patel S, Griffith B. COVID-19-associated acute hemorrhagic necrotizing encephalopathy: CT and MRI features. Radiology 2020:201187. doi: 10.1148/radiol.2020201187.

4. Sedaghat Z, Karimi N. Guillain Barre syndrome associated with COVID-19 infection: a case report. J Clin Neurosci 2020;S0967-5868(20)30882-1. doi: 10.1016/ j.jocn.2020.04.062

5. Toscano G, Palmerini F, Ravaglia S, et al. Guillain-Barré syndrome associated with SARS-CoV-2. N Engl J Med 2020;NEJMc2009191. doi: 10.1056/NEJMc2009191.

6. Kim JE, Heo JH, Kim HO, et al. Neurological complications during treatment of Middle East respiratory syndrome. J Clin Neurol 2017;13:227-233.

7. Yamana M, Kuwahara M, Fukumoto Y, Yoshikawa K, Takada K, Kusunoki S. Guillain-Barre syndrome and related diseases after influenza virus infection. Neurol Neuroimmunol Neuroinflamm 2019;6:e575. doi: 10.1212/NXI 0000000000000575 . 


\section{Neurology ${ }^{\circ}$ Clinical Practice}

Guillain-Barré Syndrome Associated With COVID-19

Seyed Amir Ebrahimzadeh, Abdoreza Ghoreishi and Nasrin Rahimian

Neurol Clin Pract 2021;11;e196-e198 Published Online before print May 21, 2020

DOI 10.1212/CPJ.0000000000000879

This information is current as of May 21, 2020

\begin{tabular}{|c|c|}
\hline $\begin{array}{l}\text { Updated Information \& } \\
\text { Services }\end{array}$ & $\begin{array}{l}\text { including high resolution figures, can be found at: } \\
\text { http://cp.neurology.org/content/11/2/e196.full.html }\end{array}$ \\
\hline References & $\begin{array}{l}\text { This article cites } 7 \text { articles, } 1 \text { of which you can access for free at: } \\
\text { http://cp.neurology.org/content/11/2/e196.full.html\#\#ref-list-1 }\end{array}$ \\
\hline Subspecialty Collections & $\begin{array}{l}\text { This article, along with others on similar topics, appears in the } \\
\text { following collection(s): } \\
\text { COVID-19 } \\
\text { http://cp.neurology.org//cgi/collection/covid_19 } \\
\text { Guillain-Barre syndrome } \\
\text { http://cp.neurology.org//cgi/collection/guillainbarre_syndrome }\end{array}$ \\
\hline Permissions \& Licensing & $\begin{array}{l}\text { Information about reproducing this article in parts (figures,tables) or in } \\
\text { its entirety can be found online at: } \\
\text { http://cp.neurology.org/misc/about.xhtml\#permissions }\end{array}$ \\
\hline Reprints & $\begin{array}{l}\text { Information about ordering reprints can be found online: } \\
\text { http://cp.neurology.org/misc/addir.xhtml\#reprintsus }\end{array}$ \\
\hline
\end{tabular}

Neurol Clin Pract is an official journal of the American Academy of Neurology. Published continuously since 2011, it is now a bimonthly with 6 issues per year. Copyright $\odot 2020$ American Academy of Neurology. All rights reserved. Print ISSN: 2163-0402. Online ISSN: 2163-0933.

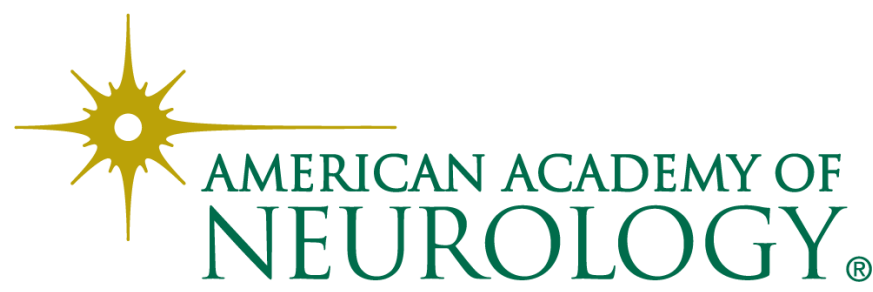

